\title{
Pengaruh Model Pembelajaran Kooperatif Team Assisted Individualization Berbantuan Media Semi Konkret Terhadap Kompetensi Pengetahuan Matematika
}

\author{
*I Gusti Agung Inten Prabaningrum1, I Ketut Adnyana Putra²
}

${ }^{123}$ Prodi Pendidikan Guru sekolah Dasar, Universitas Pendidikan Ganesha, Singaraja, Indonesia

\section{A R T I C L E I N F O}

\section{Article history:}

Received 15 August 2019 Received in revised form 20 September 2019 Accepted 10 October 2019 Available online 27 November 2019

\section{Kata Kunci:}

TAI, kompetensi

pengetahuan matematika

Keywords:

team assisted

individualization,

mathematics knowledge

competency

\begin{abstract}
A B S T R A K
Penelitian ini bertujuan untuk mengetahui perbedaan yang signifikan kompetensi pengetahuan matematika antara kelompok siswa yang dibelajarkan melalui model pembelajaran team assisted individualization berbantuan media semi konkret dan kelompok siswa yang dibelajarkan melalui pembelajaran konvensional pada siswa kelas V SD. Jenis penelitian yang digunakan yaitu eksperimen semu dengan design nonequivalent control group design. Populasi penelitian meliputi seluruh siswa kelas V SD pada semester genap sebanyak 378 orang. Sampel penelitian ditentukan dengan teknik random sampling. Sampel dalam penelitian ini dibagi menjadi 2 kelompok, kelompok eksperimen dengan menggunakan model pembelajaran team assisted individualization berbantuan media semi konkret berjumlah 39 siswa sedangkan kelompok kontrol sebanyak 44 siswa. Metode pengumpulan data dalam penelitian ini adalah metode tes, tes pilihan ganda biasa. Berdasarkan hasil analisis data, diperoleh thitung $=6,601$ dan tabel pada taraf signifikansi $5 \%,=2,000$. Hal ini berarti thitung $>$ tabel, sehingga terdapat perbedaan yang signifikan kompetensi pengetahuan matematika antara kelompok siswa yang dibelajarkan melalui model pembelajaran team
\end{abstract} assisted individualization berbantuan media semi konkret dan kelompok siswa yang dibelajarkan melalui pembelajaran konvensional. Dengan demikian dapat disimpulkan bahwa model pembelajaran team assisted individualization berbantuan media semi konkret berpengaruh signifikan terhadap kompetensi pengetahuan matematika siswa kelas V SD.

\begin{abstract}
A B S T R A C T
This research aims to determine the significant difference in mathematics knowledge competency between groups of students who were taught through the learning model of the assisted individualization team assisted by semi-concrete media and groups of students who were taught through conventional learning in fifth grade students of Elementary School. The type of this research was a quasi-experimental design with nonequivalent control group design. The population included all class $V$ in the even semester as many as 378 students. The research sample was determined by random sampling technique. The sample in this research was the VA class totalled 39 students as the experimental group and VB totalled 44 students as the control group. The method of data collection in this research was the test method and the multiple choice test. Based on the results of data analysis, obtained $t=6.601$ and $t$ table at the significance level of $5 \%,=2,000$. This meant that $t$ count $>t$ table, so that there was a significant difference in mathematical knowledge competency between groups of students who were taught through the learning model of individualized assisted teams assisted by semi-concrete media and groups of students who were taught through conventional learning. Thus it could be concluded that the learning model of assisted individualization team assisted by semiconcrete media had a significant effect on the mathematics knowledge competency on the fifth grade of Elementary School.
\end{abstract}




\section{Pendahuluan}

Pendidikan memiliki peran yang sangat penting dalam membentuk individu menjadi Sumber Daya Manusia (SDM) yang berkualitas dan mampu menghadapi perkembangan Ilmu Pengetahuan dan Teknologi (IPTEK) serta menghadapi perkembangan dalam segala bidang kehidupan, maka dari itu perlu untuk dikembangkan diberbagai ilmu pengetahuan, karena pendidikan yang berkualitas dapat meningkatkan kecerdasan suatu bangsa. Untuk mewujudkan itu semua diperlukan proses pembelajaran yang tersusun atas sejumlah komponen atau unsur yang saling berkaitan satu dengan lainnya. Interaksi antara guru dan siswa pada saat pembelajaran memegang peran penting untuk mencapai tujuan yang diinginkan.

Teori pendidikan merupakan landasan dan pijakan awal dalam pengembangan praktik pendidikan, misalnya pengembangan kurikulum, manajemen sekolah dan proses belajarmengajar. Kurikulum dan pembelajaran memiliki keterkaitan dengan teori pendidikan atau dalam penyusunan suatu kurikulum dan rencana pembelajaran ini mengacu pada teori pendidikan ((Sholichah, 2018)).

Undang-undang Sistem Pendidikan Nasional No. 20 Tahun 2003 menyatakan bahwa pendidikan nasional bertujuan untuk mengembangkan potensi peserta didik agar menjadi manusia yang beriman dan bertakwa kepada Tuhan Yang Maha Esa, berakhlak mulia, sehat, berilmu, cakap, kreatif, mandiri dan menjadi warga negara yang demokratis serta bertanggung jawab. Hal tersebut berarti bahwa pendidikan harus menjadi skala prioritas yang utama agar manusia mempunyai arah dan tujuan yang jelas mengenai apa yang akan dikerjakan dan dipilih untuk memenuhi kebutuhan hidupnya. Salah satu yang ditempuh oleh pemerintah untuk meningkatkan kualitas pendidikan yaitu penyempurnaan kurikulum tingkat satuan pendidikan (KTSP) menjadi kurikulum tahun 2013. "Kurikulum 2013 dikembangkan atas dasar teori "pendidikan berdasarkan standar" (standar-based education) dan teori kurikulum berbasis kompetensi" ((Ketut \& MD, 2014). Pembelajaran dengan menerapkan kurikulum tahun 2013 menggunakan pendekatan saintifik.

Menurut permendikbud no 103 Tahun 2014, pendekatan saintifik adalah proses pembelajaran yang dirancang sedemikian rupa agar siswa secara aktif mengonstruk konsep, prinsip, melalui pendekatan saintifik yaitu mengamati, menanya, mengumpulkan informasi, mengasosiasi, dan mengomunikasikan. Kurikulum berbasis kompetensi yang menggunakan pendekatan saintifik dirancang untuk memberikan pengalaman belajar seluas-luasnya bagi peserta didik untuk mengembangkan sikap, keterampilan, dan pengetahuan yang diperlukan untuk membangun kemampuan yang dimilikinya. Berbagai konsep dan wawasan baru tentang pembelajaran di sekolah telah muncul dan berkembang seiring pesatnya ilmu pengetahuan dan teknologi. Salah satunya dalam pendidikan Matematika.

Susanto (2015:185) menyatakan bahwa, "Matematika merupakan salah satu disiplin ilmu yang dapat meningkatkan kemampuan berpikir dan berargumentasi, memberikan kontribusi dalam penyelesaian masalah sehari-hari dan dalam dunia kerja, serta memberikan dukungan dalam pengembangan ilmu pengetahuan dan teknologi". Kebutuhan akan aplikasi Matematika saat ini dan masa depan tidak hanya untuk keperluan sehari-hari, tetapi terutama dalam dunia kerja, dan untuk mendukung perkembangan ilmu pengetahuan. Oleh karena itu, Matematika sebagai ilmu dasar perlu dikuasai dengan baik oleh siswa, terutama sejak usia sekolah dasar.

Banyak faktor yang menyebabkan rendahnya kompetensi pengetahuan Matematika yaitu di dalam dunia pendidikan proses pembelajaran belum optimal dari segi kompetensi pengetahuan siswa. Penggunaan model pembelajaran yang tidak bervariasi sehingga menyebabkan siswa merasa bosan dan tidak bersemangat dalam mengikuti pembelajaran. Pembelajaran Matematika yang sangat penting diberikan kepada siswa tapi sayang anggapan dari siswa sangat sulit dan menakutkan.

Hal ini dapat diperkuat oleh observasi yang telah dilaksanakan di SD Gugus I Kuta. Pada hari Rabu tanggal 6 Februari 2019 dengan guru kelas V (lima) di masing-masing SD Gugus I Kuta, diperoleh bahwa nilai kompetensi pengetahuan Matematika siswa kelas V (lima) sebagian besar masih berada di bawah nilai Kriteria Ketuntasan Minimal (KKM). Dimana KKM untuk kompetensi pengetahuan Matematika yang di harapkan dalam Kurikulum 2013 adalah 71,00. Dari 378 jumlah siswa kelas V yang berada di SD Gugus I Kuta, 11 siswa mendapat nilai (A), 9 siswa mendapat nilai (A-), 36 siswa mendapat nilai (B+), 44 siswa mendapat nilai (B), 25 siswa mendapat nilai (B-), 48 siswa yang mendapat nilai $(\mathrm{C}+$ ), 55 siswa yang mendapat nilai (C), 63 siswa yang mendapat nilai (C-), 45 siswa yang mendapat nilai (D+), 42 siswa yang mendapat nilai (D). Dari 378 jumlah siswa kelas V sebanyak 125 Siswa sudah mencapai KKM, sedangkan $66 \%$ dari 253 siswa yang belum mencapai KKM. Hal ini mengindikasikan bahwa ketuntasan belajar pada muatan materi Matematika di SD Gugus I Kuta tersebut belum terpenuhi dan perlu mendapat penanganan yang serius. Melihat kondisi seperti itu, perlu kiranya melakukan pengembangan dan peningkatan mutu dalam pembelajaran Matematika, yakni pembelajaran yang mampu mengoptimalkan interaksi setiap elemen untuk menumbuh kembangkan kemampuan berpikir. 
Upaya mengembangkan kemampuan berpikir salah satunya dapat dilakukan dengan jalan membangun pemahaman pada diri siswa. Peranan guru sangat penting dalam proses pembelajaran yaitu guru memiliki kekuasaan penuh untuk mengatur dan menentukan proses pembelajaran. Tenaga kependidikan yang dalam hal ini adalah guru dianggap sebagai faktor yang berperan penting dalam proses pendidikan. "Guru sebagai ujung tombak dalam pelaksanaan pendidikan merupakan pihak yang sangat berpengaruh dalam proses pembelajaran" (Susanto, 2015:92). Sehingga diperlukan guru yang profesional, yang memiliki kemampuan membelajarkan dan membimbing sesuai dengan standar pendidikan guna meningkatkan kualitas pendidikan.

Peningkatan kualitas pendidikan sangat bergantung pada berbagai faktor pendidikan yang memiliki pengaruh antara satu dengan yang lainnya dalam menciptakan suatu pembelajaran yang efektif. Salah satu faktor yang mempengaruhi efektivitas pembelajaran adalah model pembelajaran yang digunakan oleh guru dalam melaksanakan suatu proses pembelajaran. Salah satunya adalah model pembelajaran inovatif yang dapat diterapkan untuk meningkatkan efektivitas pembelajaran dan menyentuh pada pembelajaran bermakna yaitu pembelajaran kooperatif .

Model pembelajaran lebih sempurna apabila didukung dengan penggunaan media pembelajaran, salah satunya dengan memanfaatkan media semi konkret. Media semi konkret dapat diartikan dalam semi adalah sebagian dan konkret adalah nyata/benar-benar ada. Jadi model pembelajaran semi konkret adalah alat atau bahan dalam proses pembelajaran yang digunakan untuk menyampaikan pesan kepada siswa menggunakan bentuk media tersebut setengah nyata. Artinya, media tersebut bisa berupa gambar benda-benda nyata (Ketut \& MD, 2014).

"Manfaat penerapan pembelajaran kooperatif yakni dapat memaksimalkan belajar siswa untuk peningkatan prestasi akademik dan pemahaman baik secara individu maupun kelompok, mengurangi kesenjangan pendidikan khususnya dalam wujud input pada level individual. Selain itu, belajar kooperatif dapat mengembangkan solidaritas sosial di kalangan siswa. Dengan belajar kooperatif, kelak akan muncul generasi baru yang memiliki prestasi akademik yang cemerlang dan memiliki solidaritas sosial yang kuat" (Trianto, 2015:109).

Mencermati berbagai permasalahan dan realita belajar sebagaimana diuraiakan di atas, model kooperatif tipe Team Assisted Individualization tepat digunakan untuk memecahkan masalah tersebut. Model pembelajaran kooperatif tipe Team Assisted Individualization dikembangkan sebagai variasi model pembelajaran, agar kompetensi pengetahuan Matematika dapat tercapai. Team Assisted Individualization terjemahan bebas dari istilah bantuan individual dalam kelompok (BidaK) dengan karakteristik bahwa tanggung jawab belajar adalah pada siswa. Oleh karena itu, siswa harus membangun pengetahuan tidak menerima bentuk jadi dari guru. Penggunaan tim belajar empat anggota berkemampuan campur, dan menggabungkan pembelajaran kooperatif dengan pengajaran individual.

Team Assisted Individualization merupakan sebuah program pedagogik yang berusaha mengadaptasikan pembelajaran dengan perbedaan individual siswa secara akademik. Pengembangan model pembelajaran kooperatif tipe TAI dapat mendukung praktik-praktik ruang kelas, seperti pengelompokan siswa, pengelompokan kemampuan di dalam kelas, pengajaran terprogram, dan pengajaran berbasis komputer. "Tujuan model pembelajaran kooperatif tipe Team Assisted Individualization adalah untuk meminimalisasi pengajaran individual yang terbukti kurang efektif, selain juga ditunjukan untuk meningkatkan kompetensi pengetahuan, kemampuan, serta motivasi siswa dengan belajar kelompok" (Huda, 2014:200).

Penerapan model pembelajaran kooperatif tipe team assisted individualization dalam proses pembelajaran mampu membuat materi yang disampaikan lebih mudah dipahami oleh siswa, siswa mampu menggali pengetahuannya sendiri, siswa juga merasa senang dan antusias selama proses pembelajaran sehingga dapat menyelesaikan masalah yang diberikan. Terjadinya interaksi dalam kelompok dapat melatih siswa menerima anggota kelompok lain yang berkemampuan dan berlatar belakang berbeda. Siswa bertanggung jawab memberi penjelasan kepada temannya sebagai anggota kelompok belajar. Kerjasama antar anggota dalam kelompok akan tercipta, karena siswa merasa bahwa keberhasilan kelompok ditentukan oleh masing-masing anggota dalam menyelesaikan tugas yang diberikan. Setelah tumbuhnya motivasi untuk belajar yang disebabkan oleh pengaruh kerja kelompok kemampuan belajar berkembang sehingga kompetensi pengetahuan Matematika memperoleh hasil yang maksimal.

Hal ini dapat mendukung penelitian yang dilakukan oleh (Laksmi et al., 2017) bahwa penerapan model pembelajaran TAI terhadap kompetensi pengetahuan Matematika berpengaruh terhadap kompetensi pengetahuan Matematika siswa Kelas IV SD Gugus Raden Ajeng Kartini. Hal ini terlihat dari rata-rata eksperimen diperoleh 78,1 lebih dari rata-rata kelompok kontrol yaitu 62,26. Selain itu, dengan membandingkan hasil thitung dan $t_{\text {tabel }}$ dapat disimpulkan bahwa $t_{\text {hitung }}>t_{\text {tabel }}(7,64>1,980)$. Kemudian penelitian yang dilakukan oleh (Andi et al., 2017) bahwa penerapan model pembelajaran kooperatif tipe 
Team Assisted Individualization (TAI) berpengaruh terhadap hasil belajar IPS siswa kelas V semester ganjil di SD Gugus Raden Ajeng Kartini Denpasar Barat. Hal ini dapat dilihat dari data kompetensi pengetahuan IPS pada kelompok siswa yang dibelajarkan dengan model pembelajaran kooperatif tipe Team Assisted Individualization (TAI) cenderung tinggi, hal ini terlihat dari rata-rata eksperimen diperoleh 80,3 lebih dari rata-rata kelompok kontrol yaitu 69,37. Selain itu, dengan membandingkan hasil thitung dan tabel dapat disimpulkan bahwa $t_{\text {hitung }}>t_{\text {tabel }}$ dapat disimpulkan bahwa $t_{\text {hitung }}>t_{\text {tabel }}\left(t_{\text {hitung }} 3,73>t_{\text {tabel }} 2,000\right)$.

Penelitian ini juga didukung melalui penelitian yang dilaksanakan oleh (Susanti, 2016) bahwa penerapan model pembelajaran kooperatif tipe Team Assisted Individualization (TAI) berpengaruh terhadap hasil pembelajaran fisika di SMA. Hal ini dapat dilihat dari Hasil belajar siswa pada kompetensi pengetahuan dilakukan dengan uji-t berpasangan, analisis n-gain score dan uji ANOVA. Hasil penelitian menunjukan bahwa: penerapan model pembelajaran kooperatif tipe TAI terlaksana dengan kategori baik, hasil belajar siswa pada kompetensi pengetahuan meningkat secara signifikan pada $\alpha=0.05$ dengan n-gain score untuk kelas eksperimen sebesar 0,48, kelas replikasi I sebesar 0.51, dan kelas replikasi II sebesar 0.42 seluruhnya dalam kategori sedang, dan peningkatan hasil belajar siswa pada ketiga kelas tersebut secara statistik tidak berbeda.Pada kompetensi sikap diperoleh nilai modus pada ketiga kelas sebesar 3.00 dan termasuk dalam kategori baik. Untuk kompetensi keterampilan, diperoleh nilai rata-rata untuk penilaian kinerja dan tertulis kelas eksperimen sebesar 3.73, kelas replikasi I sebesar 3.72 dan replikasi II sebesar 3.71, hasil pesentase rata-rata respons siswa terhadap model pembelajaran kooperatif tipe TAI positif dengan kategori sangat baik, danaktivitas siswa mengalami peningkatan selama pembelajaran berlangsung.

Penelitian lain juga dilakukan oleh Adnyani, E., Sudirman, Askury (2012) bahwa pembelajaran dengan model TAI dapat meningkatkan aktivitas belajar siswa dimana dapat dibuktikan bahwa Aktivitas belajar siswa mengalami peningkatan sebesar 11,89\% yang ditunjukkan dengan peningkatan persentase aktivitas belajar siswa sebesar 30,65\% pada siklus I menjadi $42,54 \%$ pada siklus II. Walaupun persentase aktivitas belajar mengalami peningkatan akan tetapi kriteria keberhasilan tindakan tergolong dalam kriteria kurang sehingga dapat disimpulkan bahwa tindakan yang dilakukan tidak berhasil. Pembelajaran TAI dapat meningkatkan aktifitas belajar siswa sebesar 11, 89\%. Kontrol guru dalam kegiatan pembelajaran, motivasi siswa, dan kemandirian siswa sangat menentukan ketercapaian keberhasilan tindakan. Selain itu, kondisi kelas juga berpengaruh terhadap jalannya kegiatan pembelajaran di kelas. Motivasi belajar siswa dapat ditingkatkan dengan pemberian penghargaan kelompok berupa penambahan nilai atau pemberian hadiah pada kelompok dengan kriteria tertentu. Pembelajaran ini akan lebih baik jika dilaksanakan dalam kelas dengan jumlah siswa sedikit karena jika dilakukan dalam kelas besar guru akan kesulitan dalam pengalokasian waktu dalam kegiatan teaching groups. Pada kegiatan whooleclass units sebaiknya hanya berupa pemaparan materi secara ringkas dan alokasi waktu lebih ditekankan pada kegiatan teaching groups dan team study method karena kegiatan ini yang paling berpengaruh terhadap hasil belajar siswa.

Model TAI ini juga dilakukan ole Firman (2014), bahwa uji pasca Anava Scheffe menunjukkan adanya perbedaan rata-rata yang signifikan antara masing-masing kelas dan menunjukkan bahwa kelas eksperimen I merupakan kelas dengan hasil belajar terbaik. Pengaruh penerapan model TAI dengan SEM sebesar 20,82\%. Hasil belajar afektif dan psikomotorik pada kelas TAI dan SEM menunjukkan hasil yang terbaik dari ketiga kelas. Kesimpulan pada penelitian ini yaitu pembelajaran TAI dengan SEM berfasilitasi LKS menghasilkan hasil belajar terbaik. Berdasarkan hasil analisis diperoleh rata-rata hasil belajar kognitif kelas eksperimen I sebesar 84,67, kelas eksperimen II sebesar 82,41, dan kelas kontrol sebesar 76,61. Hasil uji Anava menunjukkan perbedaan rata-rata yang signifikan antara ketiga kelas.

Berdasarkan uraian yang telah dipaparkan, maka dilakukan penelitian tentang menerapkan model pembelajaran Kooperati Tipe Team Assisted Individualization berbantuan media semi konkret dan melihat pengaruhnya terhadap kompetensi pengetahuan Matematika. Oleh karena itu, dilaksanakan penelitian dengan judul "Pengaruh Model Pembelajaran Kooperatif Tipe Team Assisted Individualization Berbantuan Media Semi Konkret Terhadap Kompetensi Pengetahuan Matematika Kelas V SD Gugus I Kuta Tahun Ajaran 2018/2019".

\section{Metode}

Penelitian ini dilaksanakan di kelas V SD Gugus I Kuta Tahun Ajaran 2018/2019. Yang terdapat 6 SD negeri dan 2 SD swasta. Dikarenakan adanya asumsi perbedaan perlakuan yang terdapat di sekolah negeri dan swasta. maka dalam penelitian ini hanya dibatasi pada seluruh sekolah negeri di SD Gugus I Kuta yang terdiri daru 10 kelas yang nantinya dipilih kelas eksperimen dan kelas kontrol.

Pelaksanaan penelitian dilaksanakan pada bulan April 2019 sampai dengan bulan Mei 2019, di dua sekolah dasar negeri di Gugus I Kuta yang merupakan sampel dalam penelitian ini yaitu SDN 2 Kuta sebagai kelompok eksperimen dan SDN 5 Kuta sebagai kelompok kontrol. Penelitian pada kelompok 
eksperimen dan kelompok kontrol, terdiri atas pemberian pretest, pemberian perlakuan sebanyak 6 kali dan pemberian posttest pada kelompok eksperimen dan kelompok kontrol.

Rancangan penelitian yang digunakan dalam penelitian ini adalah penelitian kuantitatif dengan desain eksperimen semu (quasi experimental design). Bentuk desain eksperimen semu yang digunakan adalah Nonequivalent Control Group Design (Sugiyono, 2017). Dalam desain ini terdapat dua kelompok, yaitu kelompok eksperimen dan kelompok kontrol. Desain tersebut dapat diformulasikan dengan tabel 1 berikut.

Tabel 1. Rancangan Penelitian Nonequivalent Control Group Design

\begin{tabular}{lccc}
\hline \multicolumn{1}{c}{ Kelas } & Pretest & Perlakuan & Postest \\
\hline Eksperimen & 01 & $\mathrm{X}$ & 02 \\
\hline Kontrol & 03 & & 04 \\
\hline
\end{tabular}

\section{Keterangan:}

$\mathrm{O}_{1} \quad$ : Pretest pada kelompok eksperimen

$\mathrm{O}_{2} \quad$ : Posttest pada kelompok eksperimen

$\mathrm{O}_{3} \quad$ : Pretest pada kelompok kontrol

$\mathrm{O}_{4} \quad$ : Posttest pada kelompok kontrol

X : Perlakuan dengan model pembelajaran Kooperatif Tipe Team Assisted Individualization Berbantuan Media Semi Konkret

Penelitian ini dilakukan dengan menempuh langkah-langkah yang terdiri dari tiga tahapan yaitu: tahap persiapan, tahap pelaksanaan, dan tahap akhir eksperimen. Adapun uraian dari setiap tahapan yaitu pada tahap persiapan, hal yang dilakukan adalah melakukan wawancara dengan kepala gugus, menyusun RPP, mengkonsultasikan instrumen penelitian bersama wali kelas dan dosen pembimbing, mengadakan uji coba instrumen, melakukan pengundian untuk menentukan kelompok eksperimen dan kelompok kontrol, memberikan pretest, serta menguji kesetaraan data pretest dengan uji t.

Kemudian pada tahap pelaksanaan hal yang dilakukan adalah memberikan perlakuan pada kelas eksperimen berupa model pembelajaran team assisted individualization berbantuan media semi konkret sebanyak enam kali dan memberikan posttest, serta memberikan perlakuan pada kelas kontrol berupa pembelajaran konvensional sebanyak enam kali dan memberikan posttest. Pada tahap akhir eksperimen hal yang dilakukan adalah menganalisis data hasil penelitian dan melakukan uji hipotesis.

Dalam suatu penelitian untuk menentukan subjek penelitian, langkah awal yang dilakukan adalah menentukan populasi yang akan diteliti. Menurut (Wahyuni et al., 2016)“populasi merupakan keseluruhan dari objek, orang, peristiwa, atau sejenisnya yang menjadi perhatian dan kajian dalam penelitian". "Populasi merupakan wilayah generalisasi yang terdiri atas: obyek/subyek yang mempunyai kualitas dan karakteristik tertentu yang ditetapkan oleh peneliti untuk dipelajari dan kemudian ditarik kesimpulannya" (Sugiyono, 2017). Dengan demikian populasi adalah keseluruhan objek/subjek yang dijadikan kajian dalam penelitian untuk kemudian ditarik kesimpulannya. Populasi dalam penelitian ini adalah seluruh kelas V SD di Gugus I Kuta Tahun Ajaran 2018/2019. SD yang digunakan sebagai populasi dalam penelitian ini hanya SD Negeri yang terdiri dari 6 SD Negeri dengan 10 kelas.

Setelah menentukan populasi maka selanjutnya menentukan sampel penelitian. "sampel adalah bagian dari jumlah dan karakteristik yang dimiliki oleh populasi" (Sugiyono, 2017). Dengan demikian sampel merupakan bagian dari jumlah populasi yang dianggap mewakili seluruh populasi diambil dengan menggunakan teknik tertentu. Teknik yang digunakan dalam pengambilan sampel pada penelitian ini adalah teknik random sampling dengan kelasnya yang diacak, sehingga setiap kelas memiliki peluang yang sama untuk menjadi sampel penelitian. Sampel dalam penelitian ini adalah kelas VA SDN 2 Kuta sebanyak 39 siswa sebagai kelompok eksperimen dan kelas VB SDN 5 Kuta sebanyak 44 siswa sebagai kelompok kontrol.

Dalam penelitian ini terdapat dua variabel, yaitu variabel bebas dan variabel terikat. "Variabel bebas adalah variabel yang mempengaruhi" (Sugiyono, 2017) "Variabel bebas disebut juga variabel stimulus atau masukan, dilakukan oleh seseorang dalam lingkungannya yang dapat memengaruhi perilaku hasil" (Wahyuni et al., 2016)". Berdasarkan paparan para ahli tersebut dapat dirangkum bahwa variabel bebas merupakan variabel yang mempengaruhi yang menjadi sebab munculnya variabel terikat. Variabel bebas dalam penelitian ini adalah model pembelajaran team assisted individualization berbantuan media semi konkret. 
(Sugiyono, 2017) menyatakan bahwa "Variabel terikat merupakan variabel yang dipengaruhi atau yang menjadi akibat, karena adanya variabel bebas". "Variabel terikat yaitu suatu respon atau hasil. Variabel ini adalah aspek perilaku yang diamati dari organisme yang telah diberi stimulasi" (Wahyuni et al., 2016). Berdasarkan paparan para ahli tersebut dapat dirangkum bahwa variabel terikat, variabel yang dipengaruhi oleh variabel bebas, variabel terikat ini dapat kita amati melalui hasil yang ditimbulkan oleh adanya perlakuan atau pemberian treatment terhadap sesuatu yang diobservasi. Variabel terikat dalam penelitian ini adalah kompetensi pengetahuan matematika.

Data yang dikumpulkan dalam penelitian ini adalah data kompetensi pengetahuan matematika kelas V SD Gugus I Kuta. Data dikumpulkan dengan menggunakan metode tes. . "Metode tes adalah cara memperoleh data berbentuk tugas yang diberikan dan harus dikerjakan oleh seseorang atau kelompok yang di tes (Agung, 2014). Tes yang digunakan dalam penelitian ini berupa tes objektif dalam bentuk pilihan ganda biasa. Tes objektif dengan bentuk pilihan ganda biasa disusun berdasarkan indikatorindikator muatan materi matematika yang dimuat dalam kisi-kisi, dengan empat pilihan jawaban, yaitu a. b, c, d. Sebelum tes diberikan kepada kelompok eksperimen dan kelompok kontrol terlebih dahulu dilakukan uji instrumen. Pengujian terhadap instrumen penelitian digunakan untuk mendapatkan gambaran secara empirik apakah instrumen layak digunakan sebagai instrumen penelitian. Setelah dilakukan uji coba instrumen selanjutnya dilakukan uji validitas, uji daya beda, indeks kesukaran, dan uji reliabilitas untuk mendapatkan instrumen yang baik. Dari hasil uji instrumen terhadap 32 siswa, didapatkan 33 butir instrumen yang layak dipergunakan dari total keseluruhan instrumen yaitu 50 butir.

Dalam penelitian ini data yang terkumpul akan dianalisis menggunakan metode analisis statistik deskriptif dan metode analisis statistik inferensial. Data yang dianalisis berupa data gain skor dari hasil pretest dan posttest. Adapun rumus yang digunakan untuk menghitung gain skor adalah sebagai berikut:

$$
G S n=\frac{\text { Gain Skor }}{\text { Skor Max Ideal }- \text { Skor Pretest }}
$$

Keterangan:

$\mathrm{GSn} \quad=$ gain skor yang ternormalisasi

GS = gain skor (selisih skor)

Statistik deskriptif digunakan untuk menganalisis data kompetensi pengetahuan matematika pada kelompok eksperimen dan kelompok kontrol, statistik deskriptif yang dipergunakan yaitu, mean, standar deviasi, varians. Statistik inferensial adalah statistik inferensial, (sering juga disebut statistik induktif atau statistik probabilitas), adalah teknik statistik yang digunakan untuk menganalisis data sampel dan hasilnya diberlakukan untuk populasi" (Sugiyono, 2017). Teknik analisis data yang dilakukan adalah uji hipotesis menggunakan uji t, sebelum dilakukan uji hipotesis, terlebih dahulu dilakukan uji prasyarat analisis data berupa uji normalitas sebaran data dan uji homogenitas varians, apabila data berdistribusi normal dan homogen maka dilanjutkan dengan analisis statistik parametrik dengan teknik uji t dengan rumus polled varians, Dengan kriteria pengujian jika harga $t_{\text {hitung }} \leq t_{\text {tabel, }}$ maka $\mathrm{H}_{\mathrm{o}}$ diterima, dan jika harga $t_{\text {hitung }}>\mathrm{t}_{\text {tabel }}$ maka $\mathrm{H}_{\mathrm{o}}$ ditolak. Pada taraf signifikan $5 \%$ dengan $\mathrm{dk}=\mathrm{n}_{1}+\mathrm{n}_{2}-2$.

\section{Hasil dan Pembahasan}

Penelitian ini merupakan penelitian yang berbentuk quasi experiment atau eksperimen semu yang menggunakan rancangan nonequivalent control group design yang dianalisis menggunakan uji t. Objek dalam penelitian ini adalah kompetensi pengetahuan matematika kelas V SD Gugus I Kuta Tahun Ajaran 2018/2019. yang dibelajarkan melalui model pembelajaran kooperatif tipe team assisted individualization berbantuan media semi konkret dan yang dibelajarkan dengan pembelajaran konvensional.

Pada awal penelitian kelompok eksperimen dan kelompok kontrol diberikan pretest, setelah diberikan pretest kelompok eksperimen dibelajarkan dengan model pembelajaran kooperatif tipe team assisted individualization berbantuan media semi konkret dan kelompok kontrol dibelajarkan melalui pembelajaran konvensional sebanyak 6 kali, dan pada akhir penelitian kelompok eksperimen dan kelompok kontrol diberikan posttest, hasil pretest dan posttest dari kedua kelompok kemudian diolah menjadi data gain skor. Berdasarkan hasil gain skor diperoleh rata-rata kelompok eksperimen adalah 0,61 lebih dari kelompok kontrol yaitu 0,32. Kemudian rata-rata gain skor ternormalisasi kompetensi pengetahuan matematika pada kelompok eksperimen dan kelompok kontrol dikonversikan pada tabel pengkategorian PAN skala lima. Setelah dikonversikan pada pengkategorian PAN skala lima, rata-rata kompetensi pengetahuan matematika kelompok eksperimen berada pada kategori Cukup Baik dan kelompok kontrol berada pada kategori Cukup Baik. 
Tabel 2. Deskripsi Data Gain Skor Kompetensi Pengetahuan Matematika Kelompok Eksperimen

\begin{tabular}{cc}
\hline Standar Deviasi & 0,22 \\
\hline Varians & 0,05 \\
Rata-rata & 0,61 \\
Skor Maksimum & 0,91 \\
Skor Minimum & 0,08 \\
\hline
\end{tabular}

Tabel 3. Deskripsi Data Gain Skor Kompetensi Pengetahuan Matematika Kelompok Kontrol

\begin{tabular}{cc}
\hline Standar Deviasi & 0,16 \\
\hline Varians & 0,03 \\
Rata-rata & 0,32 \\
Skor Maksimum & 0,68 \\
Skor Minimum & 0,06 \\
\hline
\end{tabular}

Berdasarkan data gain skor kompetensi pengetahuan matematika, yang berdistribusi normal dan varians yang homogen, diperoleh hasil uji t dengan harga thitung $=6,601$, harga ini kemudian dibandingkan dengan harga tabel pada taraf signifikansi $5 \%(\alpha=0,05)$ dengan dk $(39+44-2=81)$, sehingga diperoleh harga tabel $=2,00$. Oleh karena harga thitung $=6,601>$ harga ttabel $=2,00$, maka $\mathrm{H}_{0}$ ditolak. Berikut disajikan rekapitulasi hasil analisis data dengan menggunakan uji t pada tabel 4 .

Tabel 4. Rekapitulasi analisis uji t

\begin{tabular}{cccccc}
\hline No & Nama Sekolah & thitung & Dk & tabel & Keterangan \\
\hline 1 & Kelompok Eksperimen & 6,601 & 81 & 2,000 & $\mathrm{H}_{0}$ Ditolak \\
& $\begin{array}{c}\text { (Kelas VA SDN 2 Kuta) - } \\
\text { Kelompok Kontrol } \\
\text { (Kelas VB SDN 5 Kuta) }\end{array}$ & & & & \\
& & & & & \\
\hline
\end{tabular}

Hal ini berarti terdapat perbedaan yang signifikan kompetensi pengetahuan matematika antara kelompok siswa yang dibelajarkan melalui model pembelajaran team assisted individualization berbantuan media semi konkret dengan kelompok siswa yang dibelajarkan melalui pembelajaran konvensional pada kelas V SD Gugus I Kuta Tahun Ajaran 2018/2019. Dengan demikian model pembelajaran kooperatif tipe team assisted individualization berbantuan media semi konkret berpengaruh signifikan terhadap kompetensi pengetahuan matematika kelas V SD Gugus I Kuta Tahun Ajaran $2018 / 2019$.

Berdasarkan perolehan nilai kompetensi pengetahuan matematika siswa pada kedua kelompok, dapat diketahui bahwa kedua kelompok yang awalnya memiliki kemampuan yang setara. Setelah diberikan perlakuan pada kelompok eksperimen, perolehan nilai kompetensi pengetahuan matematika mengalami perbedaan. Kompetensi pengetahuan matematika siswa pada kelompok eksperimen lebih baik apabila dibandingkan dengan kompetensi pengetahuan matematika pada kelompok kontrol. Perbedaan hasil kompetensi pengetahuan matematika pada kelompok eksperimen dan kelompok kontrol disebabkan oleh perlakuan berupa model pembelajaran kooperatif tipe team assisted individualization berbantuan media semi konkret yang diberikan kepada kelompok eksperimen.

Pada kegiatan pembelajaran di kelompok eksperimen menggunakan model pembelajaran team assisted individualization berbantuan media semi konkret berjalan secara optimal dan kondusif. Hal ini disebabkan model pembelajaran team assisted individualization berbantuan media semi konkret merupakan model pembelajaran yang membuat siswa lebih termotivasi, karena dengan penggunaan kelompok dalam belajar yang terdiri dari 4-5 orang, yang tentunya kelompok ini bersifat heterogen. Dipastikan heterogen karena adanya tes penempatan dalam pembentukan setiap kelompok, memiliki perbedaan individual siswa secara akademik dalam menyelesaikan tugas untuk mencapai tujuan bersama dan kompetensi matematika yang maksimal. Hal ini menuntut siswa secara aktif untuk menemukan informasi dan membangun pengetahuannya sendiri dengan memberi permasalahan yang diselesaikan secara berkelompok serta saling menghargai pendapat sehingga terciptanya solidaritas sosial yang kuat di kalangan siswa. Selain itu pemberian skor dan penghargaan (recognition) kepada tim atau kelompok yang memenuhi kriteria sebagai "tim super", juga akan menumbuhkan motivasi dan minat setiap siswa untuk 
lebih tekun dan bersemangat mengalahkan kelompok lain dalam menyelesaikan suatu permasalahan yang diberikan, sehingga proses pembelajaran akan menjadi lebih aktif dan terciptanya rasa senang dalam belajar matematika. Didalam proses pembelajaran dengan menggunakan model team assisted individualization dibantu dengan adanya media semi konkret, adanya media semi konkret membuat siswa lebih aktif dalam kegiatan pembelajaran dan meningkatkan kreativitas serta kemampuan berpikir kritis siswa dalam penyelesaian masalah.

Pembelajaran dengan menggunakan model pembelajaran team assisted individualization berbantuan media semi konkret khususnya pada muatan materi matematika bab penyajian data tunggal memberikan kesempatan yang lebih luas kepada siswa untuk mengkontruksikan pengetahuannya dengan penyelesaian masalah bersama kelompok, masalah yang diberikan berdasarkan pemahaman dan kehendaknya, yang membuat keaktifan, kreatifitas dan kemampuan berpikir kritis siswa meningkat.

Dengan demikian, pembelajaran menggunakan model pembelajaran team assisted individualization berbantuan media semi konkret pada penelitian ini memiliki keunggulan, yaitu. (1) Meningkatkan hasil belajar, (2) Meningkatkan motivasi belajar, (3) Mengurangi perilaku yang mengganggu dan konflik antar pribadi. (4) Siswa yang lemah dapat terbantu dalam menyelesaikan masalah. (5) Siswa diajarkan bagaimana bekerjasama dalam suatu kelompok. (6) Siswa yang pandai dapat mengembangkan kemampuan dan keterampilannya. (7) Adanya rasa tanggung jawab dalam kelompok dalam menyelesaikan masalah. Hasil temuan penelitian pada penelitian ini memiliki persamaan dengan penelitian yang relevan sebelumnya dan memperkuat hasil penelitian yang diperoleh. Hal ini didukung oleh hasil penelitian (Laksmi et al., 2017) yang menyimpulkan bahwa terdapat perbedaan yang signifikan terhadap kompetensi pengetahuan matematika yang dibelajarkan dengan model pembelajaran TAI terhadap kompetensi pengetahuan matematika siswa kelas IV SD Gugus Raden Ajeng Kartini Tahun Pelajaran 2016/2017. Begitu pula dengan hasil penelitian (Andi et al., 2017) yang menyimpulkan bahwa model pembelajaran kooperatif tipe Team Assisted Individualization (TAI) berpengaruh terhadap hasil belajar IPS siswa kelas V semester ganjil di SD Gugus Raden Ajeng Kartini Denpasar Barat.

\section{Simpulan dan Saran}

Berdasarkan hasil analisis data kompetensi pengetahuan matematika kelompok siswa yang dibelajarakan melalui model pembelajaran team assisted individualization berbantuan media semi konkret pada siswa kelas V SD Gugus I Kuta Tahun Ajaran 2018/2019, diperoleh nilai rata-rata $=0,61$, standar deviasi $=0,22$, varians $=0,05$, dan nilai maksimum pada kelompok eksperimen adalah 0,91 , nilai minimum adalah 0,08. Dikonversikan pada tabel PAN skala lima, sehingga dapat diketahui kompetensi pengetahuan matematika siswa kelas eksperimen berada pada kategori Cukup baik.

Sedangkan berdasarkan hasil analisis data kompetensi pengetahuan matematika kelompok siswa yang dibelajarakan melalui pembelajaran konvensional pada siswa kelas V SD Gugus I Kuta Tahun Ajaran $2018 / 2019$, diperoleh nilai rata-rata $=0,32$, standar deviasi $=0,16$, varians $=0,03$, dan nilai maksimum pada kelompok kontrol adalah 0,68, nilai minimum adalah 0,06. Dikonversikan pada tabel PAN skala lima, sehingga dapat diketahui kompetensi pengetahuan matematika siswa kelas kontrol berada pada kategori Cukup Baik.

Dengan demikian, dapat dinyatakan bahwa terdapat perbedaan yang signifikan kompetensi pengetahuan matematika siswa yang dibelajarkan melalui model pembelajaran team assisted individualization berbantuan media semi konkret dan yang dibelajarkan menggunakan pembelajaran konvensional pada siswa kelas V SD Gugus I Kuta Tahun Ajaran 2018/2019.

Hal ini terbukti dari hasil analisis uji t kompetensi pengetahuan matematika kelompok siswa yang dibelajarkan melalui model pembelajaran team assisted individualization berbantuan media semi konkret dan kelompok siswa yang dibelajarkan melalui pembelajaran konvensional pada siswa kelas V SD Gugus I Kuta Tahun Ajaran 2018/2019, diperoleh harga thitung $=6,601>$ harga tabel $=2,00$, maka Ho ditolak. Hal ini berarti terdapat perbedaan yang signifikan kompetensi pengetahuan matematika antara kelompok siswa yang dibelajarkan melalui model pembelajaran team assisted individualization berbantuan media semi konkret dan kelompok siswa yang dibelajarkan melalui pembelajaran konvensional pada siswa kelas V SD Gugus I Kuta Tahun Ajaran 2018/2019.

Berdasarkan pemaparan tersebut dapat disimpulkan bahwa model pembelajaran team assisted individualization berbantuan media semi konkret berpengaruh signifikan terhadap kompetensi pengetahuan matematika kelas V SD Gugus I Kuta Tahun Ajaran 2018/2019.

Berdasarkan hasil penelitian, pembahasan dan simpulan, maka diajukan beberapa saran kepada beberapa pihak sebagai berikut. (1) Kepada Guru, Penelitian ini agar bisa dijadikan acuan untuk meningkatkan keterampilan dalam merancang pembelajaran dengan tujuan memperoleh hasil belajar yang optimal. Guru yang mengajar menggunakan tematik disarankan untuk mengembangkan inovasi 
pembelajaran dengan menerapkan strategi, pendekatan, model, metode, dan media yang mampu mengoptimalkan hasil belajar siswa. (2) Kepada Kepala Sekolah, kepala sekolah diharapkan memberikan sosialisasi secara berkelanjutan mengenai inovasi-inovasi pembelajaran kepada guru dalam membelajarkan siswa agar dapat mengoptimalkan hasil belajar siswa sehingga mutu sekolah menjadi semakin meningkat. (3) Kepada peneliti lain, Peneliti lainnya, bahwa dalam penelitian ini terbatas pada pokok materi Penyajian Data Tunggal siswa kelas V. Untuk memperoleh kompetensi yang berbeda dan pada muatan materi yang berbeda peneliti menyarankan kepada peneliti lain supaya melakukan penelitian pada pokok bahasan materi yang lebih beragam untuk memperoleh hasil yang lebih baik.

\section{Daftar Rujukan}

Adnyani, E, Sudirman, Askury. (2012). Penerapan Pembelajaran Team Assisted Individualization (TAI) Dalam Pembelajaran Matematika Untuk Meningkatkan Aktivitas Belajar Siswa Kelas VIII SMP Ardjuna Malang.

Agung, A. A. G. (2014). Metodologi Penelitian Pendidikan. Aditya Media Publish.

Andi, I. P., Arsana, B., Jampel, I. N., \& Kusmariyatni, N. (2017). Pengaruh Model Pembelajaran Kooperatif Tipe Stad Ips Kelas Iv Sd Universitas Pendidikan Ganesha. 5(1).

Ketut, S., \& MD, S. I. (2014). Peningkatan Hasil Belajar Siswa Menggunakan Metode Problem Soving Dalam Pembelajaran IPA. Learning, 1(2), 75-82.

Firman, F., Antonius, Nurhayati. (2014). Pengaruh Model Team Assisted Individualization Dengan Structure Exercise Method Terhadap Hasil Belajar. https://www.e-jurnal.com/2016/06/pengaruhmodel-team-assisted.html.

Laksmi, N., Wiarta, I. W., \& ... (2017). ... Model Pembelajaran Kooperatif Tipe Team Assisted Individualization Terhadap Kompetensi Pengetahuan Matematika Siswa Kelas Iv. Mimbar Pgsd ..., 5(2), 1-10. http://ejournal.undiksha.ac.id/index.php/JJPGSD/article/view/10646

Sholichah, A. S. (2018). Teori-Teori Pendidikan Dalam Al-Qur'an. In Jurnal Pendidikan Islam (Vol. 07, Issue 1). https://doi.org/10.30868/EI.V7

Sugiyono. (2017). Statistiak untuk Penelitian. Alfabeta.

Susanti, W., Jatmiko, B. (2016). Implementasi Model Pembelajaran Kooperatif Tipe TAI (Team Assisted Individualizaton) Untuk Meningkatkan Hasil Belajar Fisika Siswa SMA Pada Materi Elastisitas (Vol 6, No 1. https://journal.unesa.ac.id/index.php/jpfa/article/view/882

Wahyuni, H. T., Setyosari, P., \& Kuswandi, D. (2016). Implementasi Pembelajaran Tematik Kelas 1 Sd. Edcomtech, 1(2), 129-136. 